高齢者で認められたすくみ足を主徵とする例の臨床的検討

一皮質下白質障害例执よび純粋アキネジア例の

MRI・SPECT 所見を中心に一

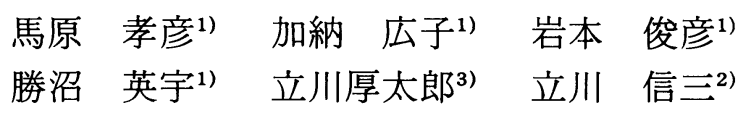

く要 約〉 高齢者でみられたすくみ足の病態を知る目的で，その神経放射線学的所見から臨床的に 検討した。

対象はすくみ足を主徵とする高齢者 4 例（すくみ足群：平均年齢79.2歳）で, 他のパーキンンン症状 を伴うものや，すくみ足に L-dopa が有効であったものは除外してある.臨床的にはいずれも下肢の肢節 運動失行なく, 前頭葉徵候はあっても軽度で, kinésie paradoxaleを認めた。 また 1 例（症例 4) は “L-dopa 無効の純粋アキネジァ”の臨床像と一致していた。

すくみ足群の CT 像では, 症例 $1 \sim 3$ で皮質下白質に軽度低吸収域を, また MRI ( $T_{2}$ 強調画像) では 同部位の広範な高信号域 (症例 2 では両側前頭葉皮質下白質に限局)を認めたが，これらは Binswanger 型脳梗塞に近似した所見であった。一方症例 4 ではMRI でのみ基底核等に点状高信号域を数個認めた。

次にすくみ足の無い Binswanger 型脳梗塞症例 6 例をコントロールとし, 皮質血流分布 ( ${ }^{123}$ I-IMP SPECT による）を比較検討した結果，すくみ足群（症例 1 ～3）で前頭葉の相対的集積低下を認めた. 症例 4 では L-threo-DOPS 投与前後の RI カウント比を検討したが, 症状の改善とともに前頭葉での RI カウント比の軽度増加を認めた。

以上から高齢者におけるすくみ足の病態のひとつに，皮質下白質の不全軟化に加光，前頭葉皮質のよ り強い血流低下の関与が示唆された。

Key words：すくみ足, 純粋アキネジア, ビンズワンガー型脳梗塞, 核磁気共鳴像, SPECT 像

\section{緒言}

『すくみ足』は『歩行先行』との異同 ${ }^{1}$ が問題となる が，一般に『すくみ足とは, 歩行開始時や方向転換時 などに足が床に張り付いたよらになってしまら現象』 と定義尕されるごとく，すくみ足はむしろ症候学的な 言葉と考えられる。本論文では，「歩行失行」はより病 態的が言葉，「すくみ足」は症状そのものを指している 言葉として使用した。

このすくみ足はパーキンンン病ばかりか, その他の 疾患, たと光ば脳血管障害や正常圧水頭症でも時に認 められる，特に高齢者ではすくみ足そのものを主徵と

1) T. Umahara, H. Kano, T. Iwamoto, H. katsunuma：東京医科大学老年病学教室

2) S. Tachikawa：立川総合病院表町病院内科

3) K. Tachikawa : 同 リハビリセンター

受付日：1990.10.1, 採用日：1990.11.21
する例も経験されるが，その病因や責任病巣について は不明な点も多い，今回画像所見を中心に，高齢者で 認められたすくみ足を主徵とする例を臨床的に検討し た.

\section{対象および方法 I}

対象はすくみ足を主徵とし, 他のパーキンソン症状 はあっても軽度で, しかも L-dopa が無効な高齢者 4 連続例（男 3 例, 女 1 例, 平均年齢79.2歳）で, パー キンソン病, 線条体異質変性症, 正常圧水頭症（以下 $\mathrm{NPH}$ )は神経症候学的に否定されている。これらをす くみ足群として，その臨床所見，頭部 CT-MRI 所見を 検討した。

MRI は常電導0.22テスラまたは0.5テスラを使用 し, $\mathrm{T}_{2}$ 強調像として longSE 法, プロトン密度（以下 $\mathrm{P})$ 強調像, $\mathrm{T}_{1}$ 強調像として IR 法, shortSE 法を用い た. 


\section{結果 I}

すくみ足群の臨床所見は表 1 に示した。すなわち症 例 1 には右上肢のわずかな麻瘏と感覚障害を認めたも のの，脳卒中の既往は 4 例ともみられなかった， 3 例 には高血圧があり，しかも 2 例の血圧は著明な変動(

表 1 すく久足群の臨床所見

\begin{tabular}{|c|c|c|c|c|}
\hline 症例 & 1 & 2 & 3 & 4 \\
\hline age/sex & $81 / \mathrm{F}$ & $77 / \mathrm{M}$ & $82 / \mathrm{M}$ & $78 / \mathrm{M}$ \\
\hline $\begin{array}{l}\text { 既往歴 } \\
\text { 高血圧 } \\
\text { 脳卒中その他 }\end{array}$ & $\begin{array}{c}+ \\
\text { (変動性) } \\
-\end{array}$ & $\begin{array}{l}+ \\
-\end{array}$ & $\begin{array}{c}+ \\
\text { (変動性) } \\
-\end{array}$ & - \\
\hline $\begin{array}{l}\text { すくみ足 } \\
\text { 経過 } \\
\text { kinesis } \\
\quad \text { paradoxale } \\
\text { L-dopa·塩酸フマンタジン } \\
\text { の効果 } \\
\text { 髄液採取後の改善 }\end{array}$ & $\begin{array}{c}3 \text { 年 } \\
+ \\
\pm \\
+\end{array}$ & $\begin{array}{c}20 \text { 年 } \\
+ \\
- \\
-\end{array}$ & $\begin{array}{c}8 \text { 年 } \\
\pm \\
- \\
\pm\end{array}$ & $\begin{array}{c}2.5 \text { 年 } \\
+ \\
- \\
-\end{array}$ \\
\hline $\begin{array}{l}\text { 臨床徵候 } \\
\text { 長谷川式スケール } \\
\text { 精神障害・ } \\
\text { 自発性の低下 }\end{array}$ & 8 点 & $\begin{array}{c}23 \text { 点 } \\
-\end{array}$ & 18点 & $\begin{array}{c}32.5 \text { 点 } \\
-\end{array}$ \\
\hline $\begin{array}{l}\text { 前頭葉徵候 } \\
\text { 言語障害 } \\
\text { 書字障害 }\end{array}$ & $\begin{array}{l}- \\
- \\
-\end{array}$ & $\begin{array}{l} \pm \\
+ \\
\pm\end{array}$ & $\begin{array}{l}- \\
- \\
-\end{array}$ & $\begin{array}{l}- \\
+ \\
+\end{array}$ \\
\hline 運動麻痺 & $\begin{array}{l}\text { 右上肢 } \\
\text { 軽度 }\end{array}$ & - & - & $\begin{array}{c}\text { (小字症) } \\
-\end{array}$ \\
\hline tremor/rigidity & - & - & - & - \\
\hline $\begin{array}{l}\text { 下肢運動失行 } \\
\text { 感覚障害 }\end{array}$ & \begin{tabular}{|c}
\multicolumn{1}{c}{-} \\
右半身 \\
表在軽度
\end{tabular} & - & $\begin{array}{l}- \\
-\end{array}$ & $\begin{array}{l}- \\
-\end{array}$ \\
\hline 尿失禁 & - & - & - & - \\
\hline $\begin{array}{c}\text { 髄液検查 圧 } \\
\left(\mathrm{cmH}_{2} \mathrm{O}\right)\end{array}$ & 8 & 10 & 9.5 & 10.5 \\
\hline
\end{tabular}

フェジピン徐放剂 $40 \mathrm{mg} / \mathrm{day}$ 投与にて, 日内変動とし て120/70 180/100mmHg 前後)を示した. 長谷川式痴 呆スケールは症例毎にまちまち(dementia-normal)で あったが，精神障害や自発性の低下は少なく，人格も 比較的保たれていた。言語では失語なく，症例 2 ・4 ですくみ言語を認めるのみであった，古典的な前頭葉 徵候(把握反射, 緊張性足底反射, Gegenhalten, 保続) はないか，あっても軽度であった。少脳症状，深部知 覚障害もなく, 構成失行, 観念運動失行, 手指失認, 左右失認もみられなかった。 また『足で円を描く，ボー ルを蹴るまねをする』などの指示に対する運動遂行に も障害はなく，下肢の肢節運動失行はないものと考兄 た. 全例に kinésie paradoxale を認めたが，症例 4 が 最も典型的であった。

髄液検査ではいずれも圧，性状ともに異常を認めな かった. 髄液採取 $(10 \sim 20 \mathrm{~m} l)$ 後の寸くみ足の改善は, 症例 3 に打いてわずかに短期間みられたのみであっ た.

症例 4 は, 症例 1 〜 とは異なり, いわゆる“LDOPA 無効の純粋アキネジア”3) (以下 pure akinesia) の臨床像と一致した。すなわち78歳の男性で， 2,3 年 間続く歩行障害に対し，近医よりパーキンソン病とし て L-DOPA・塩酸アマンタジンが投与されていた，症 状の改善なく，診察時すく久現象がみられた。歩行開 始時すくみ足が強く，一歩の前進も困難であったが， 視覚または聴覚刺激で数メートルの直線歩行は可能で あった。この症状は L-threo-DOPS600mg 投与によっ て著明に改善した。また小声で早口，吃り気味の構音 障害々小字傾向のある書字障害を認めたが，その他の 神経学的異常所見はみられなかった。

表 2 すく久足群(症例 $1 \sim 3$ ) と対照例群の画像所見の比較

\begin{tabular}{|c|c|c|c|c|c|}
\hline & 症 例 1 & 症 例 2 & 症 例 3 & 症 例 4 & 対照例群 \\
\hline $\mathrm{CT}$ & $\begin{array}{l}\text { 皮質下白質の } \\
\text { 軽度 LDA }\end{array}$ & PVLのみ & $\begin{array}{l}\text { 皮質下白質の } \\
\text { 軽度 LDA }\end{array}$ & 異常を認めず & $\begin{array}{l}\text { 皮質下白質の } \\
\text { 軽度 LDA } \\
\text { (症例 } 1 ・ 3 \text { と同様) }\end{array}$ \\
\hline MRI & $\begin{array}{l}\text { 皮質下白質の } \\
\text { 広範な高信号域 }\end{array}$ & $\begin{array}{l}\text { 前頭葉皮質下 } \\
\text { 白質の高信号域 }\end{array}$ & $\begin{array}{l}\text { 皮質下白質の } \\
\text { 広範な高信号域 }\end{array}$ & $\begin{array}{l}\text { 基底核や皮質下 } \\
\text { 白質に数個の点 } \\
\text { 状高信号域のみ }\end{array}$ & $\begin{array}{l}\text { 皮質下白質の } \\
\text { 広範な高信号域 } \\
\text { (症例 } 1 \cdot 3 \text { と同様) }\end{array}$ \\
\hline SPECT & $\begin{array}{l}\text { や前頭葉優位 } \\
\text { の皮質全体の低 } \\
\text { 集積傾向 }\end{array}$ & $\begin{array}{l}\text { 左前頭-側頭葉 } \\
\text { を中心とした低 } \\
\text { 集積傾向 }\end{array}$ & $\begin{array}{l}\text { や前頭葉優位 } \\
\text { の皮質全体の低 } \\
\text { 集積傾向 }\end{array}$ & $\begin{array}{l}\text { L-threo-DOPS } \\
\text { 投与後に前頭葉 } \\
\text { で RI カウント比 } \\
\text { が軽度増加 }\end{array}$ & $\begin{array}{l}\text { 各例とも明らか } \\
\text { な異常集積域を } \\
\text { 認めず }\end{array}$ \\
\hline
\end{tabular}


CT 所見は表 2 のごとく，症例 1 ～ 3 で特に前頭葉 の皮質下白質に吸収度のわずかな低下と軽度の脳萎 縮，脳室扗大を認めた。一方 MRI は，症例 1 と 3 で皮 質下白質に広範な信号強度の変化（P 強調像で高信号 域，IR 法で低信号域）を示した（図 1・2）。すなわち $\mathrm{P}$ 強調像における高信号域の特徵は, 辺縁が明瞭で, 皮 䯣境界に沿った外方凸の独特な曲線を呈し，前額断お よび矢状断でも脳室側から皮質直下まで及ぶ広範な高 信号域が明瞭に描出された。また T1強調像における 白質の变化は不均一・不整な低信号域で，左右差を示 し，基底核部の小軟化巣，いわゆるラクネを伴ってい た。症例 2 の白質の変化（図 1 ）は，左大脳半球でや
や大きいが，前頭葉に限局して認められた．以上から すく久足群のうち症例 1 3の共通した病変の分布は 前頭葉皮質下白質で,その形態学的特徵より Binswan-

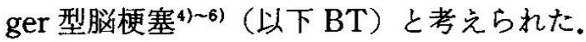

一方症例 4 では, 症例 1〜3 とは異なり, CT 上は異 常を認めず，MRIでも基底核，皮質下白質に小点状高 信号域を数個認めるのみであった。他には $T_{1}$ 強調像矢 状断面での脳幹被蓋部と底部の前後径測定值》)を含め て，異常を指摘出来なかった（図 2 ）.

\section{対象および方法 II}

次に MRIにてBT と診断された症例で，歩行障害
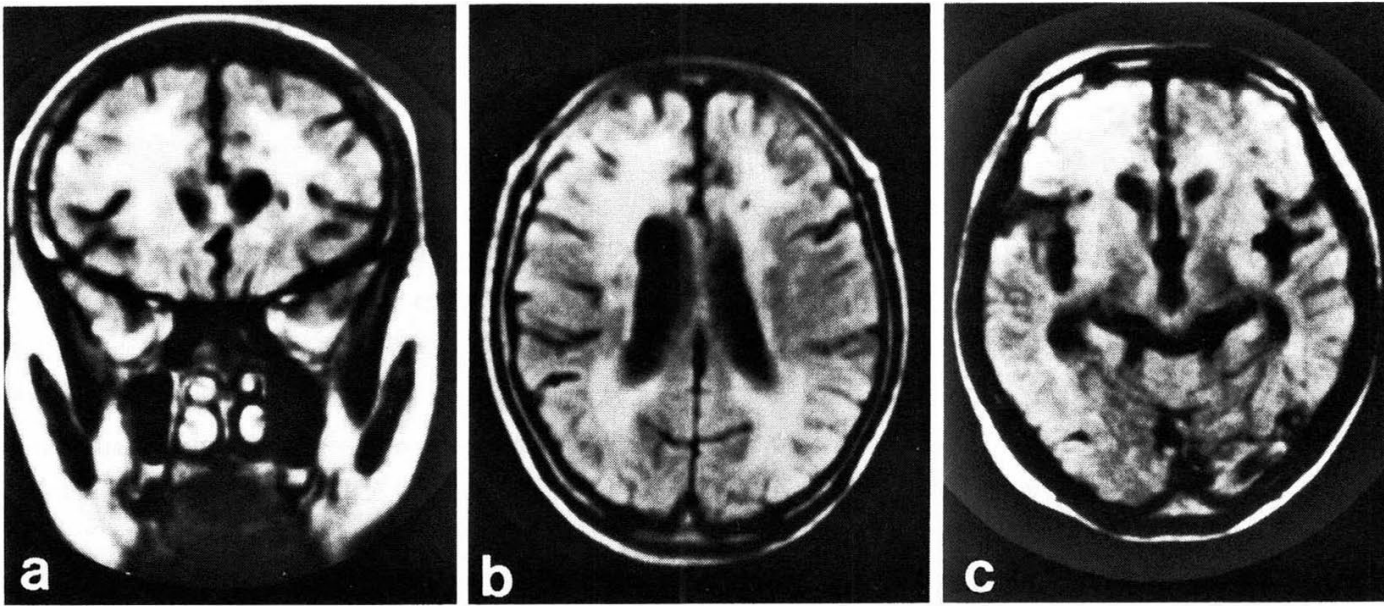

図 $1 \mathrm{a}$ ：症例 1 の MRI 像前額断面（プロトン密度強調画像：SE 2,000/40）。b：症 例 1 の MRI 像体軸断面(プロトン密度胎調画像：SE 2,000/40). c : 症例 2 の MRI 像体軸断面（プロトン密度強調画像：SE 2,000/40）
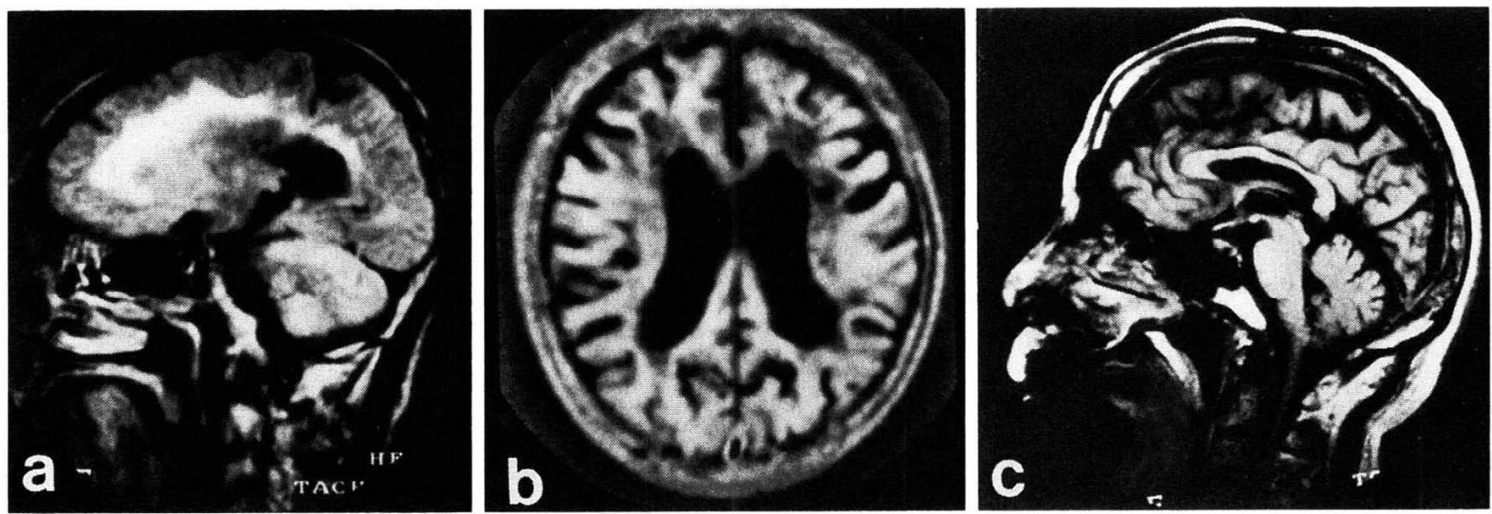

図 $2 a$ : 症例 3 のRI 像矢状断面 (プロトン密度強調画像: SE 2,000/40). b : 症 例 3 の MRI 像体軸断面 ( $T_{1}$ 強調画像：IR 2,000/500/30). $\mathrm{c}$ ：症例 4 の MRI 像矢 状断面 ( $\mathrm{T}_{1}$ 強調画像 : SE 500/30) 

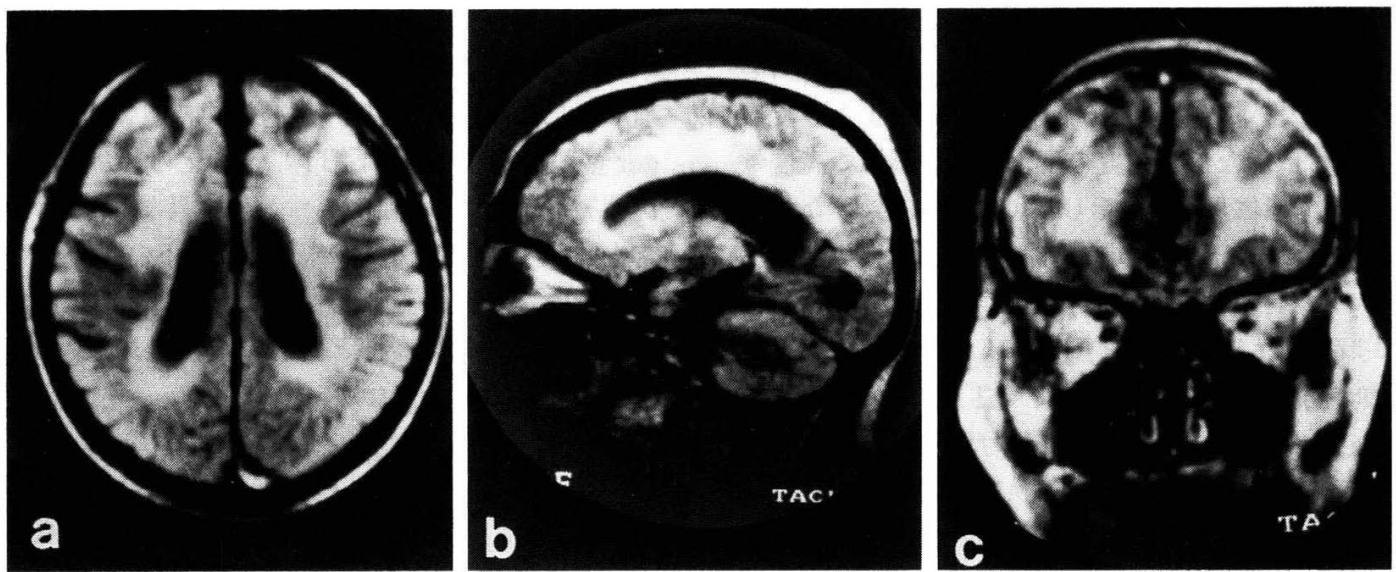

図 3 コントロール群の MRI 像（プロトン密度強調画像：SE 2,000/40）

$\mathrm{a}$ ：体軸断面, b：矢状断面, $\mathrm{c}$ ：前額断面

が無いか，あっても軽い小刻み歩行を呈した 6 例（男 3 例, 女 3 例, 平均年龄 $80,2 \pm 5.2$ 歳)をコントロール 群（図 3 ）として，脳血流分布を比較検討した。コン トロール群の長谷川式痴呆スケールは predementiasubnormal で, 運動麻㾝, 感覚麻痷, 錐体外路徵候を 各々 2 例， 1 例， 2 例に認めた。

脳血流分布は ${ }^{123}$ I-IMP SPECT（回転型ガンマカメ ラ, スライス厚 $6 \mathrm{~mm}$, 早期画像)を用い, 患者を安静 開眼状態とし, ${ }^{123} \mathrm{I}-\mathrm{IMP}$ (約 $5 \mathrm{mCi}$ ) 静注（症例 4 のみ $6 \mathrm{mCi}$ ）にに撮像し，視覚的に評価した。

またすくみ足群症例 4 (pure akinesia 例) において は，L-threo-DOPS 投与前後の ${ }^{123}$ I-IMP SPECT 所見 を, RI カウント比 (関心領域/高カウント側一側小脳) にて検討した。

\section{結果 II}

SPECT (早期画像) 所見では，すくみ足群 (症例 1 ～3）（図 4) がコントロール群（図 5) に比して皮質 全体で集積低下の傾向を示し, 特に症例 1 ・ 3 に拈い ては両側前頭葉, 症例 2 では左前頭一側頭葉の相対的 な低集積域が目立った，症例 4 (pure akinesia 例) の SPECT 所見（図 6) を L-threo-DOPS 投与前後で比較 すると, 前頭葉の関心領域でのみ RIカウント比 5 〜20\%の増加を認めた。

\section{考案}

一般にすくみ足は akinesiaの一表現型としてのす く又現象や，前頭葉障害時に起こるとされている歩行 失行の中核症状であると考えられるが，すくみ現象の
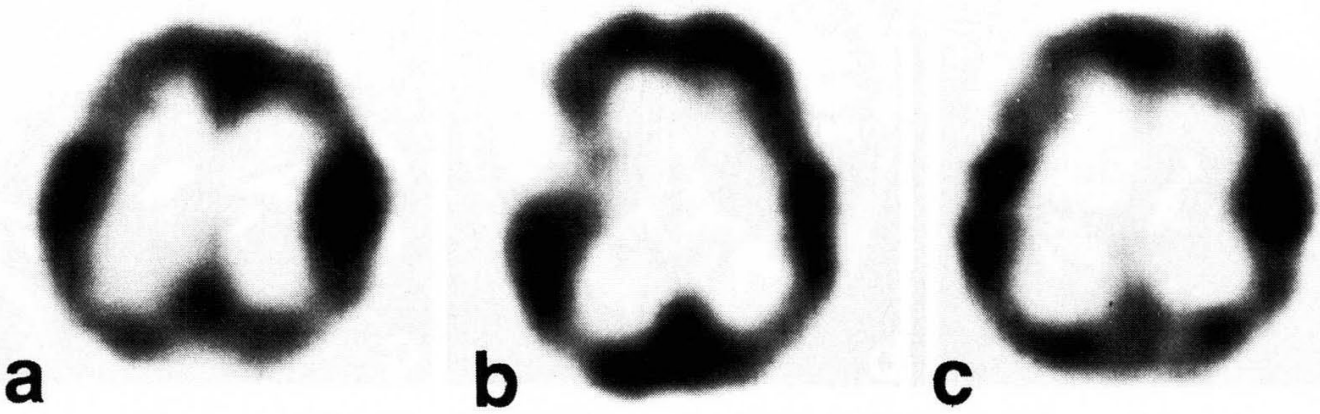

図4すくみ足足群の SPECT 像 $\mathrm{a}:$ 症例 $1, \mathrm{~b}:$ 症例 $2, \mathrm{c}$ : 症例 3 


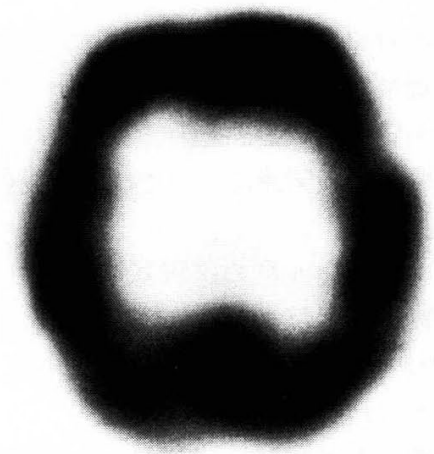

a

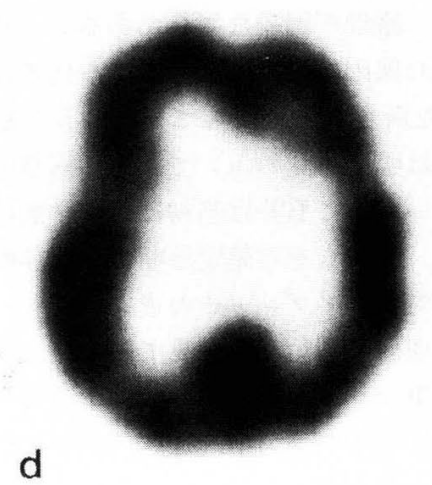

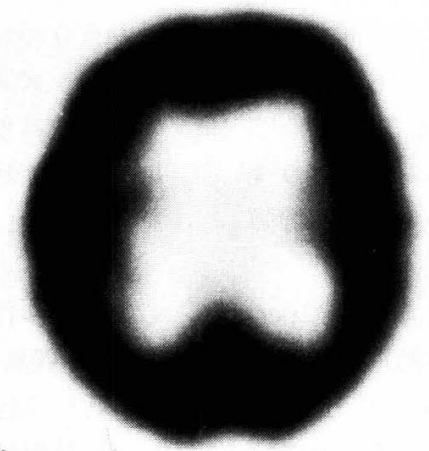

b

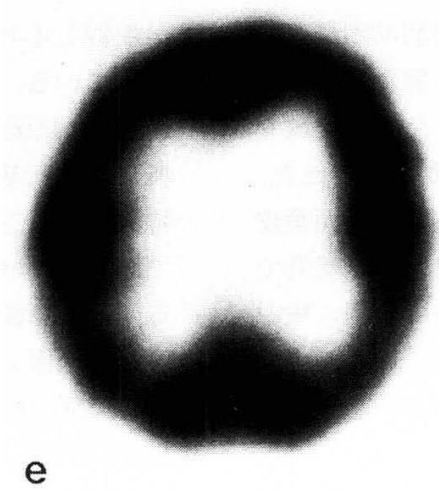

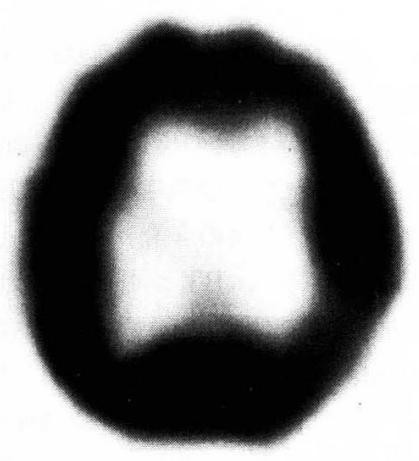

C

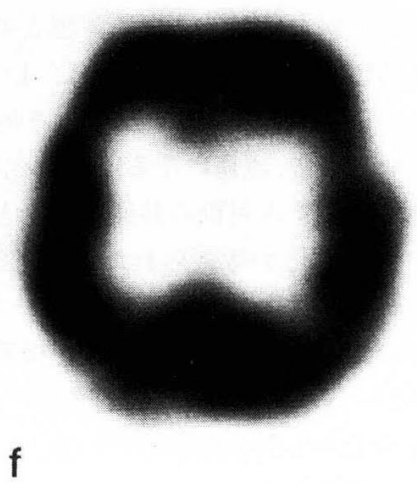

図 5 コントロール群 6 例 $(\mathrm{a} \sim \mathrm{f})$ の SPECT 像
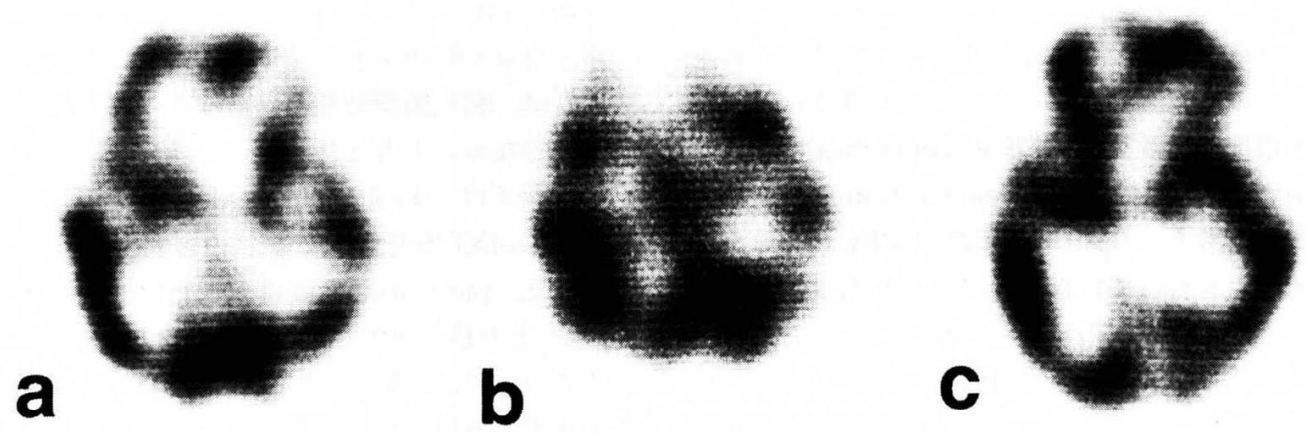

図 6 症例 4 の SPECT 像

$a, b$ : L-threo-DOPS 投与前, c：L-threo-DOPS 投与後

発生機序や歩行失行の概念は,な持論が多いところ である ${ }^{122)}$. 本研究では著者らはすくみ足を神経徽候の 一名称ととり，はっきりとした麻瘏や他のパーキンン ン症候がないのに，足が床に張り付いたようになり， このため日常生活動作が著しく障害されている4 例を すくみ足としてとら光た。ただし症例 4 は臨床的に pure akinesia と診断され, 症例 $1 \sim 3$ とは別に扱らこ ととする.

すくみ足群の MRI 所見から, 症例 1 - 3 の共通し た病变の分布は前頭葉皮質下白質であり，その形態学 的特徵から BT が考光られた. BT は高龄者では決し て稀ならずみられ, 朝長4は剖検例で約 $10 \%$ に認めら 
れたという。ささらにMRI T 2 強調画像ではその検出率 も高く, このため画像診断と病理所見との異同が問題 となるが，ここでは触れない。しかし近年 BT は脳梗 塞の一型5) (深部白質の慢性的な虚血による不全軟化) と考光られている。症例 1 と 3 は血圧の変動を伴う高 血圧の既往やラクネの多発があることから，脳血管障 害の可能性が高く, BT が強く疑われた。

一方症例 2 の側脳室前角周辺の白質変化は, periventricular hyperintensity (PVH) との鑑別が問題と なる.PVH は側脳室周囲の信号強度の変化で, 正常の ものにもみられ，また加齢とともに増加する，その意 義はまちまちで, 疾患非特異的とされるが，その広が りに決まりがないため，白質障害との鑑別は困難なこ とがある ${ }^{6)}$. 症例 2 の高信号域は，1）一部が皮質直下 に及んでいる点，2） $\mathrm{T}_{1}$ 強調像で不均一な低信号域を 呈している点で, 虚血による不全軟化巣が示唆された。

以上からすく又足群の共通な病変として, 前頭葉皮 質下白質の軟化が考兄られたが，上野8) 脳梗塞例で 認められた歩行失行（すくみ足）について詳細に検討 し，その責任病巣として前頭葉を指摘している。 また

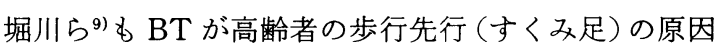
のひとつである事を報告している。

しかし BTだからといって必ずしもすくみ足を呈 するとは限らないため, 歩行障害の軽いBT 6 例とす く又群 3 例とをさらに皮質血流分布について比較検討 した. SPECTでみると, コントロール群に比べ，すく み足群で前頭葉皮質のより強い集積低下が認められ， これがすくみ足に関与していることが示唆された。

この集積低下の意味は, 梗塞巣, penumbra の存在の こともあれば, 梗塞巣周辺の deactivation に伴う血流 低下のこともある. 今回は ${ }^{123}$ I-IMP SPECT で血流量 の定量的検討を行っていないので，視覚的に評価せざ るを得ないが, 本研究のすくみ足群で認めた前頭葉の 相対的集積低下は，皮質下白質の障害がコントロール 群に比してょり強かったために，その影響がより皮質 に及んだのではないかと推測した。

以上から，すくみ足発現の機序として，両側皮質下 白質の不全軟化に前頭葉皮質血流量の低下が加わった 病態が示唆された。

一方で前頭葉は血管性痴呆の責任病巣のひとつひと つとして重要であり ${ }^{10111)}$, BT でも痴呆と関連しての 血流低下が指摘されている.

BT の臨床症状は, すくみ足や他のパーキンンニズ ムと, 痴呆とに大別できる. 各症状と脳循環代謝の関
連についての検討方法としては，まずひとつの症状の みが目立つ症例を対象に検討し, 次に複数の症状(パー キンソニズムと痴呆など）が併存しているょうな症例 の検討を行うのが望ましいと思われる，BTのすくみ 足以外の症状と脳循環の関連については, 今後の検討 を予定している。

また今回のコントロール群の選択基準として, BT の中でも歩行障害が軽度なこととしたが，抽出された 6 例は, 偶然なのか他の臨床症状も軽度であり, BT 軽 症群といら性格も合わせ持っている。

次に特発性正常圧水頭症 (以下 NPH) と BT の関連 について触れる。この両者は臨床徴候や各種画像所見 が類似しており，鑑別が困難な場合があることが指摘 されている，その原因については次のよらに考学る。 NPH は臨床的な所見のみによって規定された概念の 典型（診断基準は臨床所見のみ）であり，病理学的な 特異所見に乏しい。逆に BT は当初は病理学的に概念 であったわけで, 現在もその確定診断は病理診断であ る.この診断に対するアプローチの違いは, 同一の病 態を臨床面と病理面の別角度より見てしまい, 両疾患 の間で部分的な重なりが存在する可能性を示唆する. Akai ら ${ }^{2)} \mathrm{NPH}$ 例の病理学的検討の報告むそれら を支持するものと考学る。

よって NPH と BT の関係は複難となり, 本検討の すくみ足群に髄液循環動態の異常が合併しているかど らかの判断はむずかしい. しかし脳室払大が軽度で あった点や髄液採取ですくみ足の改善がなかったこと よりは, 䯣液循環動態の異常はあったとしても軽度で 二次的なものと考光た.

症例 4 はいわゆる pure akinesiaの臨床診断にて L-threo-DOPSを使用し症状の著明な改善を認めた例 である. pure akinesiaは, 進行性核上性麻疩 (以下 PSP) との移行 ${ }^{13) 14)}$ も指摘されて打り, その疾患部独立 性については議論も多い。しかしその特異な症状を最 も適確に表現している臨床病態名として使用されるこ ともある。

症例 4 は現時点では進行性核上性麻疸を疑わせる臨 㦿所見やMRI に扮ける脳幹被蓋部の萎縮7 は認めな かったが，その移行の問題については長期的な観察が 重要であろう。

また症例 1 ～3（白質障害を伴う）と症例 4 (pure akinesia 例) とは, 虚血性脳血管障害と変性疾患とい らまったく異なった病態を有するが，この両者は臨床 症状と CT 所見のみでは区別がやや困難であり，この 
点は留意が必要であろう。

症例 4 の L-threo-DOPS 投与後の前頭葉の若干の $\mathrm{RI}$ カウント比の上昇を, 血流増加と考㝋て良いか, も しそらだとすれば，それに対する意義だけ，すなわち， 直接に症状改善に寄与する一次的変化か, 他の変化の 結果を二次的に反映しているだけなのか,などについ ては本例のみからでは判断できない.

しかし, SPECT 所見での, 症例 $1 \sim 3$ の前頭葉の低 集積像と症例 4 の RI カウント比の上昇部位は, 共に 前頭葉を中心としたものであり, その病変分布の相似 性は, すくみ足の病態のみでなく pure akinesia の病 態を考える上でも重要な所見であろら.

またPSP 例での前頭葉の代謝・血流低下 ${ }^{15) 16)}$ 之症例 4 (pure akinesia 例) の前頭葉での RI カウント比の 変化の関連についの検討も今後重要と考える.

\section{文献}

1）水野美邦：歩行失行. 神経内科 $17: 532-537$, 1982.

2) 今井壽正：すく及足現象。神経内科 4: $309-318,1976$.

3）今井壽正：L-DOPA 無効の純粋アキネジアーす くみ現象のみを呈した症例一. 神経進歩 24 : $838-848,1980$.

4) 朝長正徳 : 老年期における痴呆と脳病変一脳血管 性痴呆に関する臨床病理学的 1 考察一. 日老医誌 13 : 198-205, 1976.

5) 岩本俊彦：Binswanger 病. Medicina 27：2488 $-2490,1990$.

6）宇高不可思, 亀山正邦：神経内科領域における magnetic resonance imaging の臨床応用一何が どこまでみえるか一、脳神経 $40 ： 423-437$, 1988.

7）馬原孝彦, 山口克彦, 宮本佳則, 勝沼英宇, 立川厚 太郎, 立川信三：MRIにおける脳幹部の検討一正 常対照例・パーキンソン病例・進行性核上性麻㾝例
に颃いて一，東医大誌 $48 ： 66-69 ， 1990$.

8）上野エリ子：歩行失行およびすくみ足の臨床なら びに生理学的検討. 臨床神経 $29: 275-283$, 1989.

9）堀川 楊, 野田恒彦, 岸田興治, 小林啓志, 皆川 信, 大浜栄作：高㱓者の歩行失行の 1 原因として の Binswanger 病一その臨床・病理と, 治療につい て一。新潟医会誌 $102: 390-398,1988$.

10）亀山正邦：痴呆の臨床と鑑別. 内科の立場から 一前頭葉連合野の血管障害と痴呆. 精神医学 $15: 357-366,1973$.

11）亀山正邦, 飯塚禮二：脳血管性痴呆. 脳卒中 11 : 646-647, 1989.

12) Akai K, Uchigasaki S, Tanaka U, Komatsu A : Normal pressure hydrocephalus neuropathological study. Acta Patol Jpn 37: 97-110, 1987.

13）本間義章, 高橋 均, 武田茂樹, 生田房弘: “LDOPA 無効の純粋アキネジァ”を呈した進行性核 上性麻痷の 1 剖検例. 脳神経 $39: 183-187$, 1987.

14）湯浅龍彦, 本間義章, 高橋 均, 森茂, 林 秀 明：純粋アキネジアで初発し，その後の経過にお いて進行性核上性麻痺と診断された 3 例. 神経内 科 $26: 460-467,1987$.

15) D'Antona R, Baron JC, Samson Y, Serdaru M, Viader F, Agid Y, Cambier J: Subcortical dementia: Frontal cortex hypometabolism detected by positron tomography in patients with progressive suppranuclear palsy. Brain $108: 785-799,1985$.

16）馬原孝彦, 立川厚太郎, 田中由利子, 久保秀樹, 山 口克彦, 立川信三, 勝沼英宇 : 前頭葉の萎縮を伴っ た進行性核上性麻疸の 1 臨床例. CT 研究 12 ： 79-84, 1990. 
Abstract

\title{
An MRI and SPECT Study of Frozen Gait without other Manifestations of Parkinsonism in the Elderly
}

\author{
Takahiko Umahara, Hiroko Kano, Toshihiko Iwamoto, Hideyo Katsunuma, \\ Kotaro Tachikawa* and Sinzo Tachikawa**
}

The authors have sometimes experienced cases of frozen gait without any other manifestations of parkinsonisms in the elderly, so we examined these cases using MR imaging and SPECT imaging. The group with frozen gait ( 4 cases, aged 78 to 82 years) which failed to respond to L-dopa therapy, had no limb-kinetic apraxia or frontal signs, but did exhibit "kinésie paradoxale". The clinical symptoms of case 4 were consistent with so-called "pure akinesia". CT findings in this group failed to elucidate the pathogenesis of frozen gait. MR imaging of all of the cases except for the case of pure akinesia (case 4) revealed a high signal intensity areas in subcortical lesions (especially the frontal area). Case 4

Department of Geriatric Medicine, Tokyo Medical College

* Rehabilitation Center, Tachikawa General Hospital (Omotemachi)

** Department of Internal Medicine, Tachikawa General Hospital (Omotemachi) had only a few spotty high-signal intensity areas. We then compared 6 cases which have the same lesions (on MRI) as cases $1 \sim 3$ without frozen gait in cases $1 \sim 3$ using ${ }^{123}$ I-IMP SPECT. Relatively low accumulation of radionuclide in the frontal area was observed in these cases. Case 4 had a slightly low perfusion area in the frontal lobe. However in the patient treated with $L$ threo-DOPS, accumulation of radionuclide in the frontal area increased slightly after L-threo-DOPS therapy. It appears that one of the reasons for frozen gait in the elderly is incomplete infarct of the subcortical white matter with a low perfusion area in the frontal cortex. Furthermore, in some cases of frozen gait it is difficult to distinguish between cases with white matter disorders and cases of pure akinesia on the basis of clinical symptons and CT alone.

key words: frozen gait, pure akinesia, binswanger type infarction, MRI, SPECT

(Jpn J Geriat 28: 377-384, 1991) 